\title{
PRESEPSI MASYARAKAT TERHADAP PELAYANAN ADMINISTRASI PADA KANTOR KELURAHAN PALANGKA KECAMATAN JEKAN RAYA
}

\author{
Betty Karya \\ Fakultas IImu Sosial dan IImu Politik Universitas PGRI Palangka Raya \\ (email: betykarya@gmail.com) \\ Dawit \\ Fakultas IImu Sosial dan IImu Politik Universitas PGRI Palangka Raya
}

\begin{abstract}
Abstrak
Tujuan penelitian ini adalah pertama, Untuk mengetahui bagaimana pelayanan administrasi yang diterapkan di Kelurahan Palangka Kecamatan Jekan Raya. Kedua, Untuk mengetahui bagaimana persepsi masyarakat terhadap pelayanan Administrasi Kelurahan Palangka Kecamatan Jekan Raya. Penulisan skripsi ini penulis menggunakan berbagai macam metode diantaranya metode library research (penelitian pustaka) yaitu dengan mencari data dengan berupa buku-buku dan metode field research (penelitian lapangan) yaitu penelitian yang dilakukan secara langsung guna memperoleh data yang erat kaitannya dengan penelitian dengan angket (questionnaire). Sampel yang digunakan adalah accidental sampling pengambilan sampel dengan mengambil individu siapa saja yang dapat dijangkau atau ditemui dengan perincian: perangkat Kelurahan Palangka sebanyak 10 orang, tokoh masyarakat 50 orang, PNS 20 orang, TNI/POLRI 20 orang. Dengan jumlah sampel semua 100 orang. Data dianalisis melalui analisis kuantitatif yaitu analisis yang berbentuk angka-angka, tabel, dan diagram. Dengan menggunakan rumus $P=\frac{f}{N} \times 100 \%$ hasil penelitian menunjukkan bahwa sistem pelayanan administrasi yang diterapkan Kelurahan Palangka Kecamatan Jekan Raya sudah sebagian besar baik dan efektif terhadap pelayanan administrasi maupun dengan sistem pelayanan masyarakat sehingga berjalan dengan maksimal.
\end{abstract}

\section{Kata kunci : Presepsi Masyarakat, Sistem Pelayanan Administrasi}

\section{Pendahuluan}

Masyarakat adalah sekelompok manusia yang merupakan satu kesatuan golongan yang berhubungan tetap dan mempunyai kepentingan yang sama. Seperti sekolah, keluarga, perkumpulan, negara semua adalah masyarakat. Masyarakat adalah suatu struktur yang mengalami ketegangan organisasi maupun perkembangan karena adanya pertentangan antara kelompok-kelompok yang terpecah karena ekonomi. (Muin 2013). 
Seiring berkembangnya zaman dan peningkatan sosial ekonomi masyarakat semakin besar pula tuntutan masyarakat terhadap sistem pelayanan perkembangan dunia usaha dan organisasi dewasa ini baik pemerintahan maupun swasta menimbulkan kesadaran berbagai pihak yang ikut serta di dalamnya untuk meningkatkan persatuan dengan meningkatkan hubungan kerja sama melalui pelayanan dan melakukan komunikasi yang baik.

Instansi pemerintahan adalah sebutan kolektif yang meliputi satuan kerja/satuan kementrian/departemen, organisasi Pemerintah Non Departemen, kesekretariat lembaga tinggi negara, dan instansi pemerintah lainnya, baik pusat maupun daerah, termasuk Badan Usaha Milik Negara dan Badan Hukum Milik Negara.

Pemerintah atau birokrasi menjadi jembatan antara aspirasi masyarakat melalui lembaga legislatif dengan masyarakat yang secara langsung menerima dan menikmati pelayanan yang diberikan oleh birokrasi, sebab pemerintah dianggap sebagai lembaga pelayanan masyarakat. Di antara lembaga pelayanan masyarakat atau instansi pemerintahan salah satunya adalah kelurahan. Kelurahan merupakan unsur perangkat daerah yang memiliki tugas pokok melaksanakan sebagian kewenangan pemerintahan yang dilimpahkan oleh bupati/walikota kepada Lurah.

Sebagai salah satu lembaga pelayanan masyarakat, fungsi dari kelurahan sendiri adalah pelaksanaan pelayanan kepada masyarakat. Artinya, sudah sepatutnya kantor kelurahan memberikan pelayanan bagi masyarakat dalam segala kebutuhan baik dalam kepengurusan administrasi kenegaraan masyarakat, maupun dalam kepengurusan surat-surat atau dokumen-dokumen penting yang membutuhkan campur tangan pihak kelurahan.

Secara umum, masyarakat merupakan costumer yang membutuhkan pelayanan publik untuk mempermudah segala urusannya terkait dengan administrasi kenegaraan. Tidak hanya sekedar mempermudah, terkadang masyarakat juga membutuhkan bimbingan dan arahan tentang kepengurusan administrasi kenegaraan. Ini yang seharusnya menjadi perhatian staf-staf yang bertugas di kantor kelurahan. Selain melayani masyarakat, mereka juga memiliki kewajiban untuk mensosialisasikan pemahaman tentang kepengurusan administrasi kenegaraan kepada masyarakat.

Seiring perkembangan zaman dan peningkatan sosial ekonomi masyarakat, tuntutan masyarakat terhadap sistem pelayanan pemerintahan dewasa ini semakin meningkat. Untuk mengatasi hal ini, staf pemerintahan harus meningkatkan hubungan kerja sama melalui pelayanan dan melakukan komunikasi yang baik dengan masyarakat.

Hal ini dapat dilakukan salah satunya dengan cara memaksimalkan hubungan masyarakat, terutama pada kantor-kantor pemerintahan maupun instansi lainnya dengan cara memberikan pelayanan yang baik bagi masyarakat. Pelayanan yang baik adalah kepedulian kepada masyarakat dengan memberikan pelayanan terbaik untuk menfasilitasi kemudahan pemenuhan kepuasan masyarakat atau disebut juga dengan pelayanan (prima).

Dalam melaksanakan tugasnya, pelayanan administrasi memerlukan sistem

\section{Jurnal Sociopolitico}


pelayanan yang baik dalam berkomunikasi dan pelayanan masyarakat, sebab hal terpenting dalam sistem pelayanan masyarakat adalah komunikasi yang disertakan dengan kecerdasan. Karena kecerdasan akan mempermudah seseorang dalam mengatur emosinya dengan baik sehingga dapat berkomunikasi dengan baik pula. Dengan begitu masyarakat akan selalu mendapatkan pelayanan yang memuaskan dan dapat sesuai dengan suasana hati yang diperlukan masyarakat sehingga hubungan antara staf dengan masyarakat dapat terjalin dengan baik.

Pelayan Administrasi yang terampil menggunakan komunikasi yang efektif yang pada akhirnya dapat mencegah timbulnya konflik antara staf dengan masyarakat. Dapat pula mengintegrasikan pelaksanaan kegiatan dalam organisasi yang menjadi perubahanperubahan kehidupan yang lebih baik dari sebelumnya, sehingga masyarakat mengalami perubahan.

Pelayanan masyarakat dapat dikatagorikan baik dan efektif apabila masyarakat mendapatkan kemudahan pelayanan dengan prosedur yang singkat, cepat, tepat dan memuaskan. Selain itu pelayan administrasi diharuskan komunikatif. Maksudnya mampu dengan cepat memahami keinginan masyarakat, selain itu berkomunikasi harus dengan bahasa yang jelas dan mudah dimengerti sesuai dengan tingkat kemampuan masyarakat yang berbeda-beda.

Jika ditilik dari beberapa keterangan di atas, dapat di tarik kesimpulan bahwa seharusnya masyarakat menerima pelayanan yang memuaskan dari pelayan administrasi kantor pemerintahan, mengingat fungsi kantor pemerintahan sendiri adalah untuk mempermudah dan menfasilitasi segala urusan masyarakat terkait kepengurusan administrasi negara.

Sistem pelayanan staf yang diberikan kepada masyarakat seperti dalam keperluan pembuatan surat menyurat, administrasi, proses pembuatan KTP dan hal lainnya di kantor kelurahan Palangka Kecamatan Jekan Raya, menimbulakan persepsi yang berbeda dikalangan masyarakat. Intinya masyarakat menginginkan pelayanan yang memuaskan. Hal ini ditujukan agar pelayanan administrasi yang diberikan kepada masyarakat senantiasa merupakan pelayanan yang aman serta dapat memenuhi kebutuhan dan harapan masyarakat. Sehingga tidak menimbulkan asumsi dan persepsi yang macam-macam dari masyarakat.

Persepsi masing-masing individu terhadap sistem pelayanan administrasi tentu berbeda-beda. Maka dari itu sistem pelayanan administrasi kelurahan Palangka Kecamatan Jekan Raya harus dengan menggunakan sistem yang dapat membantu mempermudah urusan atau keluhan masyarakat terkait kepengurusan admisnistrasi kenegaraan agar mendapatkan persepsi yang baik pula dari masayarakat.

\section{Metode Penelitian}

Pendekatan yang digunakan dalam penelitian ini adalah menggunakan pendekatan kuantitatif. Metode kuantitatif yaitu untuk menjawab masalah, tipe data penelitian yang menujukkan jumlah atau banyaknya sesuatu. Dalam penguraian hasil penelitian peneliti juga menggunakan metode kualitatif, yaitu dengan menguraikan, mencatat, mengamati terhadap objek penelitian.

Berdasarkan metodologi penelitian kuantitatif, peniliti mengambil teknik

\section{Jurnal Sociopolitico}


penelitian survei. Metode survei berarti metode pemeriksaan dan pengukuran, metode penelitian yang dilakukan untuk mengadakan pemeriksaan dan pengukuran-pengukuran terhadap gejala emperik yang berlansung di lapangan atau lokasi penelitian, umumnya dilakukan terhadap unit sampel yang dihadapi sebagai responden dan bukan terhadap seluruh populasi sasaran (Abdurrahman Fathoni, 2006: 64).

Jenis survei yang digunakan dalam penelitian ini yaitu deskriptif. Survei deskriptif yaitu survei untuk mengadakan pemeriksaan dan melakukan pengukuranpengukuran terhadap gejala empiris yang diperiksa. Kata deskriptif berasal dari bahasa inggris descriptive, yang berarti bersifat menggambarkan atau melukiskan sesuatu hal. Menggambarkan atau melukiskan dalam hal ini dapat dalam arti sebenarnya (harfiyah), yaitu berupa gambar-gambar atau foto-foto yang didapatkan dara data lapangan atau peneliti menjelaskan hasil penelitian dengan gambar-gambar dan dapat pula menjelakannya dengan kata-kata (Husaini Usman, 2009: 129).

\section{Hasil dan Pembahasan}

\section{Sistem Pelayanan Administrasi yang diterapkan di Kelurahan Palangka}

Keberhasilan mencapai tujuan dalam suatu lembaga sangat tergantung pada komunikasi yang digunakan. Dalam sistem pelayanan staf terhadap masyarakat yang terjadi di kantor Kelurahan Kota Palangka Raya, para pelayanan administrasi masih menggunakan sitem kasta; maksudnya, masyarakat yang memiliki status sosial lebih tinggi atau memiliki perekonomian tinggi akan mendapatkan pelayanan lebih memuaskan dibandingkan masyarakat yang tidak memiliki status sosial dan perekonomian rendah. (hasil wawancara dengan salah satu staf kelurahan)

Kelurahan merupakan unsur perangkat daerah yang memiliki tugas pokok melaksanakan sebagian kewenangan pemerintahan yang dilimpahkan oleh camat dan atau lurah. Sebagai salah satu lembaga pelayanan masyarakat, fungsi dari kelurahan sendiri adalah pelaksanaan pelayanan kepada masyarakat. Artinya, sudah sepatutnya kantor kelurahan memberikan pelayanan bagi masyarakat dalam segala kebutuhan baik dalam kepengurusan administrasi kenegaraan masyarakat, maupun dalam kepengurusan surat-surat atau dokumendokumen penting yang membutuhkan campur tangan pihak kelurahan.

\section{Persepsi Masyarakat Terhadap Sistem Pelayanan Administrasi Kelurahan}

Dari hasil angket yang dibagikan kepada 100 responden yang diteliti oleh penulis tentang sistem pelayanan Administrasi di Kelurahan Palangka Kecamatan Jekan Raya yang diberikan kepada masyarakat apa telah memuaskan, dapat dilihat pada tabel dibawah ini:

\section{Tabel 1}

Apakah menurut anda sistem komunikasi pelayanan administrasi Kelurahan

Palangka Kecamatan Jekan Raya dengan masyarakat terjalin dengan baik?

\begin{tabular}{|cl|cl|c|c|}
\hline & Responden & \multicolumn{2}{|c|}{ Pernyataan } & Frekunsi & Presentase \\
\hline 1. & Perangkat & 1. & Ya & 9 & $90 \%$ \\
& Kelurahan & 2. & Tidak & 1 & $10 \%$ \\
\hline 2. & Tokoh & 3. & Ya & 40 & $80 \%$ \\
& Masyarakat & 4. & Tidak & 10 & $20 \%$ \\
\hline 2. & PNS & 1. & Ya & 18 & $90 \%$ \\
& & 2. & Tidak & 2 & $10 \%$ \\
\hline 4. & TNI/POLRI & 5. & Ya & 19 & $95 \%$ \\
& & 6. & Tidak & 1 & $5 \%$ \\
\hline & Jumlah & & & 100 & 400 \\
& & & & & \\
\hline
\end{tabular}

\section{Jurnal Sociopolitico}


Tabel diatas menunjukan bahwa responden menjawab ya dikalangan Perangkat Kelurahan sebanyak 9 orang atau $90 \%$, tokoh masyarakat 40 orang atau $80 \%$, Pns 18 orang atau 90\%, dan TNI/POLRI 19 atau 95\%. Sementara responden yang menjawab tidak dikalangan Perangkat Kelurahan 1 orang atau $10 \%$, tokoh masyarakat 10 orang atau $20 \%$, Pns 2 orang atau 20\%, dan TNI/POLRI 1 atau 5\%.

Dari hasil penelitian tersebut dapat disimpulkan bahwa sebagian besar responden menjawab ya sistem pelayanan administrasi di Kelurahan Palangka Kecamatan Jekan Raya yang diberikan kepada masyarakat memuaskan. Namun ada juga responden yang menjawab tidak. Selanjutnya dapat dilihat pada diagram dibawah ini:

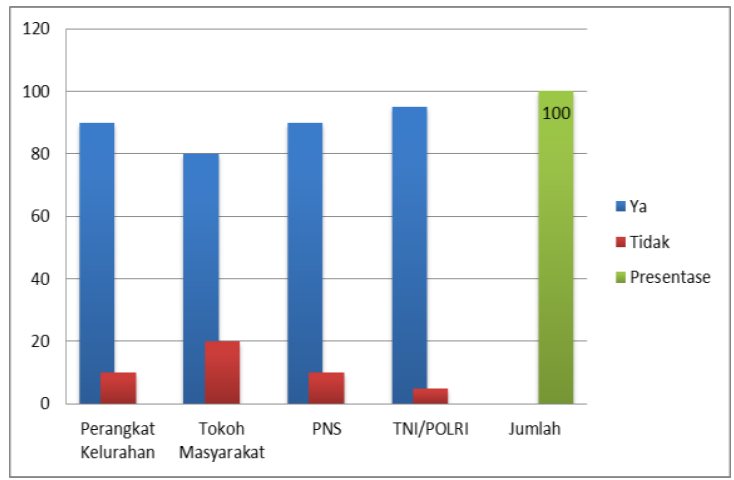

Sumber: Hasil Penelitian bulan Juli 2020

Berdasarkan hasil data yang dikumpulkan melalui data observasi dan angket, dan kemudian dihitung dengan menggunakan rumus statistik Sudjana, seperti berikut:

$$
\mathrm{P}=\frac{f}{N} x 100 \%
$$

Dimana :

$$
\begin{array}{ll}
P & =\text { Persentase } \\
F & =\text { Frekuensi } \\
N & =\text { Jumlah Sampel } \\
100 \% & =\text { Bilangan Tetap }
\end{array}
$$

Kemudian untuk hasil perhitungan besarnya presentese jawaban responden yang dijadikan dasar dari penarikan kesimpulan dengan berdasarkan pada rumus masalah penelitian,ditentukan dengan kriteria seperti yang di kemukakan oleh Sutrisno Hadi, sebagai berikut: $100 \%=$ seluruhnya

$80 \%-90 \%=$ pada umumnya

$60 \%-79 \%=$ sebagian besar

$50 \%-59 \%=$ lebih dari setengah

$40 \%-49 \%=$ kurang dari setengah

$0 \%-19 \%=$ sedikit sekali

Berdasarkan faktor psikologis setiap orang memiliki kebutuhan atau pun kepentingan individual yang berbeda dengan orang lain. Perbedaan ini akan mempengaruhi seseorang dan sehingga menimbulkan persepsi terhadap orang lain.

Sebagian besar dari masyarakat Kelurahan Palangka Kecamatan Jekan Raya mengatakan bahwa sistem pelayanan administrasi yang berlaku di kantor Kelurahan Palangka masih berdasarkan sistem kasta. Maksudnya, masyarakat yang memiliki status sosial lebih tinggi atau memiliki perekonomian tinggi akan mendapatkan pelayanan lebih memuaskan dibandingkan masyarakat yang tidak memiliki status sosial dan perekonomian rendah, sehingga masyarakat kurang memuaskan dalam menerima sistem pelayanan. Sebagaimana yang telah dijelaskan pada tabel dan diagram.

Hasil penelitian dapat membuktikan bahwa tanggung jawab pelayanan administrasi Kelurahan 
Palangka sebagian besar baik disegi tugas maupun disegi memberikan pelayanan perilaku, sikap kepada masyarakat. Sebagaimana yang telah di jelaskan pada tabel dan diagram diatas.

Hasil penelitian dapat membuktikan bahwa mengenai sistem pelayanan yang berlaku pada kantor Kelurahan Palangka saat ini sebagian besar baik bagi masyarakat, sedangkan persepsi masyarakat terhadap sistem pelayanan masih adanya perbedaan persepsi dan kurang memuaskan. Dan dalam penggunaa sistem komunikasi yang masih kurang efektif. Sebagaimana yang telah dijelaskan pada tabel dan diagram.

Masyarakat adalah sebagai warga Kelurahan Palangka setiap masyarakat mempunyai hak dalam mempersepsikan sesuatu hal atau seseorang terhadap suatu persoalan yang timbul dalam kehidupan manusia, atau adanya faktor-faktor lain yang melatar belakangi. Demikian pula dengan persepsi masyarakat terhadap sistem pelayanan administrasi di kantor kelurahan Palangka. persepsi masyarakat tehadap sistem pelayanan di kantor kelurahan sebagian besar memuaskan bagi keperluan mereka baik itu dalam proses pembuatan KTP ataupun dalam proses surat menyurat dan hal lainnya. Sebagaimana yang telas dijelaskan pada tabel dan diagram diatas.

\section{Kesimpulan}

Persepsi masyarakat terhadap
sistem pelayanan administrasi yang
diterapkan di Kantor Kelurahan Palangka
Kecamatan Jekan Raya pada umumnya
efektif dalam memberikan pelayanan
kepada masyarakat dan masih ada
beberapa responden yang masih belum
merasakan puas terhadap pelayanan yang
mereka terima, hal tersebut terbukti dari

beberapa jawaban responden pernyataan yang ada diangket.

1. Pada saat ini sistem pelayanan administrasi yang diterapkan di Kantor Kelurahan Palangka Kecamatan Jekan Raya sebagian besar sudah efektif.

2. Persepsi masyarakat terhadap sistem pelayanan administrasi Kelurahan Palangka Kecamatan Jekan Raya adalah pada umumnya sudah baik dan memuaskan. akan tetapi masih ada terdapat satu atau dua orang lagi yang masih mengganggap sistem yang diberikan kelurahan kurang memuaskan masuk dalam tabel nomor $2,4,5,6,7,9,10,11,12,14,15$.

3. Pernyataan responden mengenai sistem komunikasi pelayanan administrasi Kelurahan Palangka dengan masyarakat terjalin dengan baik masuk kedalam tabel nomor $1,3,8$.

4. Pernyataan responden mengenai ketersediaan sarana dan prasarana bagian administrasi Kelurahan masuk kedalam tabel 13.

\section{Referensi}

Abdulsyani, 2012. Sosiologi Skema, Teori, dan Terapan, Jakarta:PT Bumi Aksara.

Abdurrahman Fathoni, M.Si. 2006. Metodologi Penelitian dan Teknik Penyusunan Skripsi, Jakarta

Alo Liliweri, 2011. Komunikasi Serba Ada Serba Makna Jakarta: Kencana.

Atep, Adya Barata,S 2004. Dasar-Dasar Pelayanan Prima. Elex Media Komputindo Jakarta.

Bimo Walgito, 1994. Pengantar Psikologi Umum, Yogyakarta.

Burhan Bungin, 2001. Metode Penelitian Sosial, Surabaya: Erlangga Unisersity Press.

\section{Jurnal Sociopolitico}


Carol Wade dan Carol Travis, 2002. Psikologi, Jakarta: Penerbit Erlangga

Dadang Juliantara, 2005. Peningkatan Kapasitas Pemerintahan Daerah Dalam Pelayanan Publik, Yogyakarta : PENBAHARUAN.

Deddy Mulyana, 2005. Ilmu Komunikasi Suatu Pengantar, Bandung: PT Remaja Rosdakarya.

Effendy, Onong Uchjana. 2003. Ilmu, Teori dan Filsafat Komunikasi. Bandung: Citra Aditya Bakti.

Fandy,Tjiptono. 2008. Service Management: Mewujudkan Layanan Prima Andi. Yogyakarta.

Gibson dan James 1, 1990. Organisasi Perilaku, Struktur, Proses Jakart:Erlangga.

Husaini Usman, 2009. Metode Penelitian Sosial, Edisi Ke Dua Jakarta Bumi Aksara.

Jalinus Syah, dkk, 1999. Kamus Pelajar; Kata Serapan Bahasa Indonesia. Jakarta: Rineka Cipta.

Kurniawan. 2005. Transformasi Pelayanan Publik. Yogyakarta: Pembaharuan.

Lijan Poltak Sinambela, dkk, 2006. Reformasi Pelayanan Publik, Jakarta: PT. Bumi Aksara.

Miriam Budiardjo, 2008. Dasar-Dasar Ilmu poliik, Jakarta: PT. Gramedia Pustaka Utama.

Moenir. 1992. Manajemen Pelayanan Umum di Indonesia, Jakarta: Bumi Aksara.

Muhammad Utsman Najati, 2004. Psikologi dalam Perspektif Hadis, alih bahasa oleh Zaenuddin Abu Bakar dkk, Jakarta: Pustaka.

Muin, idianto, 2013. Sosiologi Untuk SMA/MA X Kelompok Peminatan Ilmu-Ilmu Sosial. Jakarta: Erlangga.
Mulyana, Dedi, 2008. Ilmu Komunikasi Suatu Pengantar Bandung:PT Remaja Rosdakarya.

Nasrullah Nazsir, 2009. Teori-teori Sosiologi, Bandung: Widya Padjadjaran.

Paul, B. Baran dan C.L. Hunt, 1984. Sosiologi Jilid I. Ed. 6 Jakarta: Erlangga.

Pitus A Partanto, M. Dahlan Al Barry, 2001. Kamus Ilmiah Populer Surabaya.

Punama, Nursya'bani. 2006. Manajemen Kualitas Perspektif Global. Edisi Pertama, Cetakan Pertama. Penerbit Ekonisia Kampus Fakultas Ekonomi UII Yogyakarta. 